\title{
The Development of Personal Character Through STEM Integration in Learning of Elementary School
}

\author{
Abna Hidayati \\ Universitas Negeri Padang \\ abnahidayati@fip.unp.ac.id
}

\author{
Alwen Bentri \\ Universitas Negeri Padang \\ abnahidayati@fip.unp.ac.id
}

\author{
Fetri Yeni \\ Universitas Negeri Padang \\ abnahidayati@fip.unp.ac.id
}

\begin{abstract}
The current phenomena in the field indicate that most of students have not possess the $21^{\text {st }}$ century skills namely the ability to creative thinking, autonomous, and hard work. The students tend to keen on the instant culture, especially in searching information. This study aims to develop the personal character by taking the interdisciplinary approaches among Science, Technology, Engineering and Mathematic (STEM) in course' content-based. This study utilized the research and development design method with ADDIE Model comprising of five stages, namely Analysis, Design, Development, Implementation, and Evaluation. This research is conducted in four regions in West Sumatra province, two areas that represent counties (Agam, Pasaman Barat), and the two regions represent cities (Padang and Padang Panjang). The four regions are chosen because the area has the number of character education programs largely in local schools. The sampling has been selected purposively and involving 78 elementary school students. The findings describe that there was a significant distinction between the student' personal character taught using STEM Approach and conventional methods.
\end{abstract}

Keywords: integrated learning model, character, elementary school

\section{INTRODUCTION}

Character based Learning is one of the main focuses of the educators. In 2013 curriculum, character values are the priority that becomes the consideration for the government, teachers, and parents. In accordance with the design of the study, characters stated in this curriculum are integrated to the content of the subjects. The implementation of the character-based education which is design in the context of 2013 curriculum has become the main focus because the character values designed in the previous curriculum have not been conducted completely.

Based on the 2013 curriculum structure the substantive curriculum implementation which is relied on the character based education on each subject should be implemented more compared to the previous curriculum (Sutjipto, 2011). At the elementary curriculum structure, it is said that the number of subjects was reduced from 10 pieces to 4 subjects by means of the integration of several subjects such as science and social studies. As the result of the reduction of the number of subjects in elementary school, the number of hours increased 4 hours a week. It allows the learning process in schools and the formation of the learners' character become more optimal. In addition, the learning process of elementary school students took place thematically integrated also emphasized the importance of character education in learning. states that the essential character is taught with integrated directly into the academic curriculum. This statement implies meaning that the character is very necessary to be taught optimally and in this case to there should be a character curriculum design for teachers' guidance in implementing the character based education in the classroom (Hidayati, Zaim, Darmansyah \& Rukun, 2014)

Based on the review of the curriculum in 2013 wich is character oriented, it can be seen the aspect of the character has not been significantly drawn in teacher and student book. In the book of teachers and students which become general guideline implementation of the learning process in the classroom, character values have not been the concern. Additionally, thematic system performed on the learning process in elementary has not reflected the character education curriculum implementation designed before. In the teacher and student books, especially in the fourth-grade thematic learning system is designed based on the theme and sub-themes that have been predetermined. Nevertheless, the specific learning theme has not be prepared for everyday learning activity so that the learning process will become conventional and it is not a thematic learning. The conditions certainly have an impact on learning that lasts less than optimal especially dealing with aspects of value investment character as an important part of the learning objectives have been designed. The design of character-based curriculum designed by the Ministry of National Education (Kemendiknas) is integrated to the implementation of the learning, so thematic system will let the implementation of the learning will become effective if it is designed specifically on the implementation of character values.

Observation in Pasaman Barat and Agam shows that some schools that implement the 2013 curriculum have implemented the character-based education integrated to the subjects. Nevertheless, the its implementation in elementary school level is not optimal yet, because most of the teachers still let the learning 
process focus on the learning content mastery and put little the values of character. Implementation of learning with thematic system still focused on the mastery of specific subjects and it does not lead to the learning theme so long to integrate the character values. This condition makes of course the character values are no got by the students optimally. Nevertheless, the distribution of the character values is a system that belongs to the students themselves.

Linkcona says that the character is all about the possession of something good (Dalmeri, 2014). Mulyasa (2011) says that character education is a system of cultivation of character values to learners, which includes awareness, understanding, awareness and commitment to instill these values, both to Allah Almighty God, themselves, fellow, environment, and society and the whole nation so that they become a perfect man by nature. The development of character learning model is done by using integrated model of subjects. In this concept, the character education model developed is not separated from existing learning. In this case, it takes creativity of teachers to include character values into existing learning.

Integrating the values of the character of course is started from the design implementation of the learning undertaken. Furthermore, the design is implemented in practice by teachers. Integrating the character-based education is done so that the students can have a core competence and basic competence learning thoroughly.

There are four components described by Becker and Park (2011) regarding the definition of STEM, such as: (1) science, representing the knowledge about the laws and concepts existed in the environment; (2) technology is the skills or a system to regulate the society, organization and knowledge designed to ease people's activities; (3) engineering is the knowledge to operate or design a certain procedure to solve a problem; and (4) mathematic is the knowledge to bridge among the scale, numbers and geometry which only needs logic arguments without being followed by empirical evidences. These aspects can maximize the potential of knowledge into more meaningful when it is integrated in learning process.

The purpose of the provision of education one of them is the formation of character in students as the output of education. In this case, it is necessary to consider some of the concepts that can be used in the implementation of character education in schools. The implementation of character education at the school level, one of the things that might be done is to integrate the values of characters in a number of relevant subjects.

In this concept, what is mean by a character education integrated in the learning process is the introduction of values, facilitation gained awareness of the importance of values, and internalization of values into the behavior of students through a learning process that takes place both inside and outside the classroom in all subjects. So according to this understanding, teaching character to the learners, is not given in the form of a particular subject, but only integrating these concepts in certain subjects. In the structure of our curriculum, there are two subjects that are directly related to the development of good character and noble character, namely religion and civics education.

The integration of character value in schools is possible to be implemented by managing classroom and learning environment with the nuance of character education. The facilities which should be available in classroom are trash can, whiteboard and blackboard, hand washing facilities, napkin, bucket of water, and lost itemsfinding jar (Hidayati, Amsal, \& Amilia, 2018).

The character-based learning model integrated to subjects can be made through the following stages: (1) analyzing the core competencies and basic competencies that must be owned by the students; (2) designing learning activities that is integrated to the learning material used; (3) developing character values to be covered to students; (4) developing strategies and methods of learning; (5) developing an evaluation tool; and (6) implementing the learning process effectively and efficiently. The stages of this learning can be developed according to the needs of students in the school and can be adapted to the condition of infrastructure and the ability of teachers in schools.

\section{METHODS}

This study is classified into Research and Development research design. The development model that is used uses ADDIE development model. There are five stages offered by this model, namely Analysis, Design, Development, Implementation, and Evaluation. At the analysis stage, the data for the initial observation is collected in Agam, Pasaman Barat and Padang Panjang. The results of the analysis are used to create the design of an integrated learning model character.

The next design was developed with the teachers and student's guidebook. Furthermore, the implementation in the city of Padang is done on three categories of schools that are good and less. The sampling is done purposively. Later in the assessment phase, the teachers and the curriculum experts will evaluate and assess the model developed so that this model will be declared to be valid and practical. The study was conducted to the fourth grade Elementary School students.

\section{RESULT AND DISCUSSION}

The development of an integrated learning model code on the subjects carried out in five stages of the analysis, design, development, implementation and evaluation. In the early stages, the analysis on character learning model integrated to subject is conducted.

\section{Analyzing Phase}

Analyzing phase is the first phase to develop the character learning model integrated to subject. This analysis is important because it is the basis for the researcher to the product development of character education curriculum. The analysis is done the analysis of learners, problem analysis, content analysis, context analysis and purposes analysis. Needs analysis is the process of identifying the desired change that needs to happen, who requested the changes occur and under what circumstances that change must occur.

In this case, the needs analysis is very important in helping the designer of learning in determining what needs to be developed or what kind of learning that is able to bring the desired changes. In developing the characterbased curriculum begins from the need analysis, it has 
been obtained that the character is important and a priority for learners. As previously disclosed, the main purpose of education is actually the aspect of character. The bill explained that the purpose of education is to form nationally religious students, noble, independent, honest and responsible. Planting of character values are one thing that are the focus of all educational activities undertaken by students. In this case, a needs analysis conducted through questionnaires and deepened through in-depth interviews with sources. Needs analysis process starts from the analysis of learners.

From the results of the needs analysis, it shows that most participants consider that the implementation of character education is important. In humanistic theories, humans are essentially good and essentially will strive towards better. Moral development of students depends on the aspect of cognitive development. Gredler (2011) states that the principle of cognitive development in the moral aspect that the process of thinking and knowing are created in a person with the environment, in which the social environment including the role of language and education here depicted the aspects of moral development. Further analysis is context analysis which is related to environmental conditions regarding the implementation of character education. Observations and interviews obtained information that the environment of the learners, the location of the sample implementation of character education is heterogeneous, which is located in an environment that is quite diverse with parents' job is dominated by the housewife and private, and some of them are civil servants and the other kind of employee, but few less than $30 \%$. Environmental context affects the implementation of character education. Environment in this case provides high impact on the character formation of students.

Narwanti (2011) explains that the level of achievement of the character education program run in schools depends on the environment. Schools in this case should consider the programs that support the achievement of the activity of character values in schools. Further analysis shows that the problem arises because character education problems found in the field. The dominant problems involving young people, such as fights, no respect for others, cheating and other good deeds. In connection with these conditions then the character education is needed to overcome these problems.

\section{Designing Phase}

Designing phase of learning model is the blueprint model created. The design stage is important because at this stage, the developed research products specified by initial components that will be created. This design is the basis of initial stages in product development research. Design becomes a primary basis in future product development process. In doing character design education model, integrated learning process on the subjects will be designed. As the focus of curriculum development is done is a daily activity design are made in a special theme.

The teacher and student books are only designed on themes of learning. But the draft has not been made specific daily themes. Daily Theme is designed by the researchers. The themes of daily activities designed further implemented in daily learning activities and fully prepared as an appendix to this curriculum. In the development of the integrated character education model books are designed on the subjects of integrated learning model character of subjects, user guide books for teachers and students.

\section{Development Phase}

The development phase is done by making character education model integrated subjects' book, manufacture manual and user guide book for students and teachers. Stages of development is done by designing learning experiences for students so that they can have the character values and can implement them in everyday activities. Associating with the development of student's personal character applying the STEM Approach, it is developed in the number of science and mathematics courses conducted with integrating those values in the learning process in some ways, such as: (1) students get used to searching references both online and offline to obtain particular information; (2) teachers facilitate discussion among students to inculcate the analytical and critical thinking and value and to respect someone's opinion each other; (3) teachers facilitate students to cooperate each other; (4) teachers give a highlight to positive competition among students; (5) teachers facilitate students to writing a report and result of experimental activities and group exploration; and (6) teachers facilitate students to explore the experiences of other students critically.

The STEM Approach is developed with integrating the whole supporting facilities of learning and available content including designing learning environment and laboratories to promote the implementation of character values.

\section{Implementation Phase}

Implementation of the product is the next step that is done out of character education curriculum development process. Implementation of the product means how the product has made and it is more widely tested on samples that have been determined. The implementation process is aimed to look at the practicality and effectiveness of the products that have been designed and developed.

In the course of the implementation of the educational curriculum of character that was designed which products are namely books curriculum, books teacher, student book, diary, the environmental design learning activities will be done in the learning process that is adapted to the learning process. Implementation of learning activity is about the implementation of character values which is integrated into the learning in accordance with the existing themes. In the process of learning, investigators designed a daily theme that will be implemented every day. The everyday design theme is important because in the everyday process of learning, the integrated concept of learning to include characters is needed. The themes of these learning facilitate the implementation of character education curriculum.

An important concept in the implementation phase is about how the curriculum designers were able to choose what kind of learning methods that are most 
effective in conveying the material or materials on the cultivation of character values that have been set. Selection of this method is part of an effort to attract and maintain the interest of the learners to be able to focus on the delivery of the material on character education curriculum. At this stage, the system learning is ready to be used by learners.

In this case, the product is designed to make sure that the students will know each other. In the process of the characters learning, the activities are designed to make the students know the other students. At the initial stage, the students were asked to determine the area of origin of his friends. Furthermore, those activities, continued intensively to know things that are typical of each area such as dances, typical regional food and more. In terms of responsibilities, one of which that can be done is to teach a sense of responsibility toward animals. The learners' book also provides space to give a sense of responsibility towards the tasks given to the students. In the implementation of the product conducted by researchers collaborated with classroom teachers so as the curriculum is designed to correspond to what has been planned. After implementing the values of character, tests are done on a group of students in a school with a good category and less. The result can be seen in the following Figure 1.

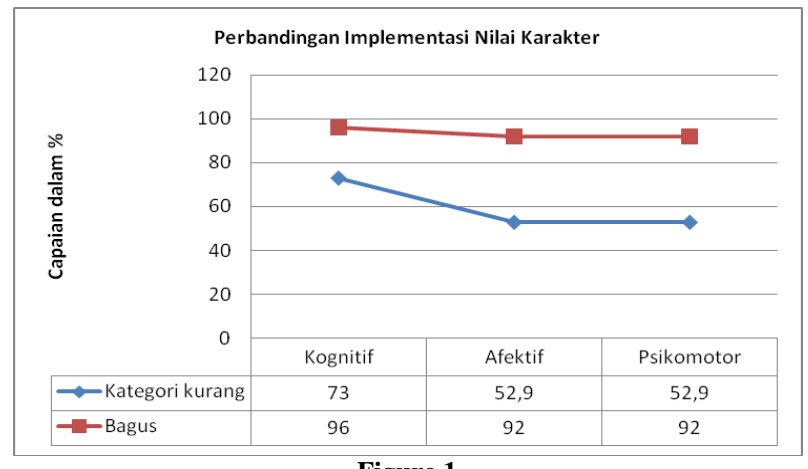

Figure 1

Comparison of Implementation of Good Character in Good and Poor School

The chart above shows that the information about the level of achievement in the implementation of the character values in good schools is above the established standard that is $75 \%$. While at school in the poor category, the average achievements were below the standard as seen in the chart above. From the above chart, it can be seen that the implementation of the values of good character on the cognitive, affective and psychomotor are in high category as mentioned on several studies that the level of ownership of the character value is directly proportional to the value of the student. This means that if the students have good marks, it can be said character is also good.

The result of difference test depicted that there was significant distinction in constructing personal characters such as creative thinking, independent, and critical attitude to elementary school students taught with STEM Approach compared to conventional class. This is based to the tests undertaken with the calculation of t-test conducted in both experimental class and control-class that the value of students' critical thinking character is around $2,412>$ t-table $=2,000$ or sig value $=0.018<=$ $5 \%$. Furthermore, there was significant distinction in constructing the students' autonomous character proved by the calculation of t-test conducted in final test in experimental class and control class, where the calculation of t-test showed that the value of independent character is $2,566>\mathrm{t}$-table $=2,000$ or sig value $=0,015$ $<=5 \%$.

In the implementation process of character values in integrating the concept of learning, it can be seen that in general, the value associated with the character and the divine aspects of oneself can be implemented on a daily basis on the learning process. The religious activities are performed by familiarizing students to pray before and after study hours, reminding the hours of prayer and many more. Furthermore, the characters that are related to the students themselves can also be implemented on nearly every existing learning process.

Based on the findings above, it is found that the STEM Approach can increase the mastery of critical thinking and independent character of students. This is because the students are commonly able to explore information well. The STEM Approach in learning is possible to improve the students' literacy skills and generally give an impact to construct personal characters of students namely critical thinking and independency. To maximize the potential of this approach, it can be utilized optimally various learning resources, analyzing learning resources, and integrating the digital devices in combining the learning resources with the information as teachers' instruction (Traill \& Traphagen, 2015)

At the implementation stage, character value is less concerned about the environment can be implemented as well. In the implementation of character education curriculum that is given to the sample schools, there is a difference in the process of planting the existing values. The condition occurs is because of the support for different input so that the process value is also different. In a school with a good category indeed there is good quality input learners and support from parents, so any school programs received positive support (Hidayati, 2018).

\section{Evaluation Phase}

Evaluation product Phase is an important part of the overall implementation of curriculum development. The essential concept of the stages of evaluation is how the ADDIE model of instructional designers was able to conduct an overall evaluation of models, from the beginning to the end (Maribe Brach, 2009). The important step in the ADDIE model evaluation is to determine the evaluation criteria, select tools for evaluation, and conduct evaluation itself.

Product evaluation activities undertaken in this case is divided into two; formative evaluation and summative evaluation. The formative evaluation is done by improving the product strategies, materials and design. Later, the summative evaluation carried out repairs on learning activities in each theme. From the evaluation, the data shows that ideally the implementation of the concept of character education should be implemented in a comprehensive manner. Integrated character education is a must in the implementation of character education. 


\section{CONCLUSION}

The STEM Approach enables to construct the students' personal characters such as critical thinking and autonomous characters as a part of particular skills needed by the $21^{\text {st }}$ century generation.

Character based education in the context of an integrated model of 2013 curriculum is carried out by integrating the characters to the subjects. Integrating character education on subjects is done by inserting the values of characters in the delivery of the subject matter. The model of character education is integrated on the subjects developed in five stages namely the analysis phase that is by analyzing the core competencies and basic competencies that will be integrated character values, the next phase of the design is designing behavior and a learning experience that will be given according to the material characteristics lesson.

Further phase of development is done by developing an integrated learning experience character. Phase implementation is done by implementing a model that has been designed for learning. In the implementation phase of learning about the characters, they are not separated, but integrated to the subjects. In the implementation phase, they are performed on the learning of related themes which the theme is about togetherness in diversity and my activity. Based on the results of the implementation found that schools with a good category whose cognitive, affective and psychomotor are higher than the less category school. Evaluation Phase is done by assessing the learning model that has been developed to obtain an effective and efficient final product. In evaluation phase, there is a repairmen of learning activities which are done in specific themes such as the theme of unity in diversity, energy and motion and peers.

\section{REFERENCE}

1. Becker, K., \& Park, K. (2011). Effects of integrative approaches among science, technology, engineering, and mathematics (STEM) subjects on students' learning: A preliminary. Journal of STEM Education (Vol. 12). https://doi.org/10.1037/a0019454

2. Dalmeri. (2014). Pendidikan untuk Pengembangan Karakter (Telaah terhadap Gagasan Thomas Lickona dalam Educating for Character). Al-Ulum, 14(1), 269-288. Retrieved from https://www.researchgate.net/publication/290920065_PEN DIDIKAN_UNTUK_PENGEMBANGAN_KARAKTER_ Telaah_terhadap_Gagasan_Thomas_Lickona_dalam_Educ ating_for_Character

3. Hidayati, A. (2018). Need Analysis of Media Video Development for Character Education at Early Childhood Education in Padang. Advances in Social Science, Education and Humanities Research (ASSEHR), 169(ICECE 2017), 108-110.

4. Hidayati, A., Amsal, M. F., \& Amilia, W. (2018). Development of classroom design model into character education in elementary. International Conferences on Education, Social Sciences and Technology, (2010), 945948.

5. Hidayati, A., Zaim, M., Darmansyah, \& Rukun, K. (2014). The Development of Character Education Curriculum for Elementary Student in West Sumatera. International Journal of Education and Research, 2(October), 37-41. https://doi.org/10.1080/15578771.2012.729551

6. Maribe Brach, R. (2009). Instructional Design: The ADDIE Approach (p. 203). Springer Publishing Company, Incorporated (02009.

7. Sutjipto. (2011). Rintisan Pengembangan Pendidikan Karakter di Satuan Pendidikan. Jurnal Pendidikan Dan Kebudayaan, 17, 501-524.

8. Traill, S., \& Traphagen, K. (2015). Assessing the Impacts of STEM Learning Ecosystems NOVEMBER 2015. 